\title{
REFORMING INTERMEDIARY LIABILITY IN THE PLATFORM ECONOMY: A EUROPEAN DIGITAL SINGLE MARKET STRATEGY
}

\author{
Giancarlo F. Frosio*
}

\begin{abstract}
Since the enactment of the first safe harbors and liability exemptions for online intermediaries like Google and Facebook, market conditions have radically changed. Originally, intermediary liability exemptions were introduced to promote an emerging internet market. Do safe harbors for online intermediaries still serve innovation? Should they be limited or expanded? These critical questions-often tainted by protectionist concerns - define the present intermediary liability conundrum. Today, safe harbors still hold, but secondary liability is on the rise. In its Digital Single Market Strategy, the European Commission plans to introduce sectorial legislation that would effectively erode liability exemptions for online intermediaries, especially platforms. In an attempt to close a "value gap" between rightholders and online platforms allegedly exploiting protected content, the proposal would implement filtering obligations for intermediaries and introduce neighboring rights for online uses of press publications. Meanwhile, an upcoming revision of the AudioVisual Media Services Directive would ask platforms to put in place measures to protect minors from harmful content and to protect everyone from incitement to hatred. Finally, the EU Digital Single Market Strategy has endorsed voluntary measures as a privileged tool to curb illicit and infringing activities online. This Essay contextualizes the recent EU reform proposal within a broader move towards turning online intermediaries into internet police. This narrative builds exclusively upon governmental or content industry assumptions, rather than empirical evidence. Also, the intermediary liability discourse is shifting towards an intermediary responsibility discourse. Apparently, the European Commission aligns its strategy for online platforms to a globalized, ongoing move towards privatization of enforcement online through algorithmic tools. This process may advance an amorphous notion of responsibility that incentivizes
\end{abstract}

\footnotetext{
* Senior Researcher and Lecturer, Center for International Intellectual Property Studies (CEIPI), Universitè de Strasbourg; Non-Resident Fellow, Stanford Law School, Center for Internet and Society. The author can be reached at gcfrosio@ceipi.edu.
} 
intermediaries' self-intervention to police allegedly infringing activities in the internet.

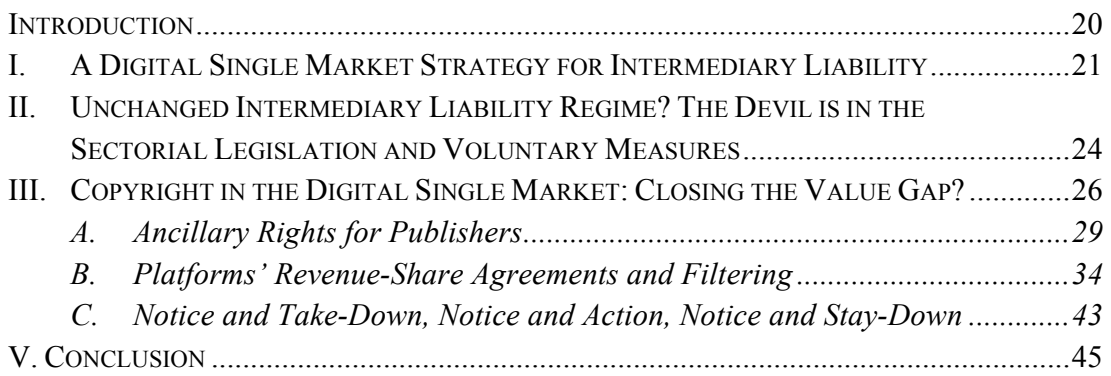

\section{INTRODUCTION}

Since the mid-nineties, legislators have provided online intermediaries, such as access or hosting providers, with exemptions from liability for wrongful activities committed by users through their services. ${ }^{1}$ In most cases, safe harbor legislations provide "mere conduit," caching, and hosting exemptions for intermediaries. Safe harbor legislation usually does not require intermediaries to monitor the information that they transmit or store, or to actively seek facts or circumstances indicating illegal activity. ${ }^{2}$ Nonetheless, recent international policy debates have recalibrated towards more secondary liability for online intermediaries. In particular, the European Commission has been seriously considering narrowing the eCommerce Directive horizontal liability limitations for

\footnotetext{
${ }^{1}$ For most worldwide safe harbor legislations, see World Intermediary Liability Map (WILMap), THE CTR. FOR INTERNET \& SOC'Y, STAN. L. SCH., http://cyberlaw.stanford.edu/our-work/projects/ world-intermediary-liability-map-wilmap [https://perma.cc/84L7-VRTU] (last visited June 3, 2017) (presenting a project designed and developed by the author).

2 See, e.g., The Digital Millennium Copyright Act of 1998, 17 U.S.C. § 512(c)(1)(A-C) (2012) [hereinafter DMCA]; Directive 2000/31, of the European Parliament and of the Council of 8 June 2000 on Certain Legal Aspects of Information Society Services, in Particular Electronic Commerce, in the Internal Market 2000 O.J. (L 178) 1, 2 (EC) [hereinafter eCommerce Directive].
} 
internet intermediaries ${ }^{3}$ and putting in place a "fit for purpose regulatory environment for platforms and intermediaries." ${ }^{4}$

\section{A DigitAl SingLE MARKET STRATEGY FOR INTERMEDIARY LIABILITY}

In May 2015, the European Union (EU) Commission issued its Digital Single Market Strategy (DSMS), announcing steps to be taken "towards a connected digital single market" and plans to reform EU copyright. ${ }^{5}$ The theme of the DSMS is "[b]ringing down barriers to unlock online opportunities" with the aim of moving the EU from "28 national markets to a single one." ${ }^{\prime 6}$ Reforms proposed by the DSMS address topics including ecommerce, cross-border sales, and copyright. ${ }^{7}$ The Digital Single Market Strategy focuses on four main issues: (1) cross-border access to content, (2) text- and data-mining, (3) civil enforcement, and (4) the role of ISPs. ${ }^{8}$ In particular, the Commission noted:

An effective and balanced civil enforcement system against commercial scale infringements of copyright is central to investment in innovation and job creation. In addition the rules applicable to activities of online intermediaries in relation to copyright protected works require clarification, given in particular the growing involvement of these intermediaries in content distribution. Measures to safeguard fair remuneration of creators also need to be considered in order to encourage the future generation of content. ${ }^{9}$

Apparently, the European Commission plans to enhance the obligations that websites and other internet intermediaries have when

\footnotetext{
3 See Patrick Van Eecke, Online Service Providers and Liability: A Plea for a Balanced Approach, 48 Common MKT. L. Rev. 1455, 1463 (2011) ("Section 4 [of the eCommerce Directive] introduces a horizontal special liability regime for the three types of service providers covered by it. Provided they meet the criteria laid down in Section 4, the service providers will be exempted from contractual liability, administrative liability, tortious/extra-contractual liability, penal liability, civil liability or any other type of liability, for all types of activities initiated by third parties, including copyright and trade mark infringements, defamation, misleading advertising, unfair commercial practices, unfair competition, publications of illegal content, etc.").

${ }^{4}$ See Communication from the Commission to the European Parliament, the Council, the European Economic and Social Committee and the Committee of the Regions, A Digital Single Market Strategy for Europe, COM (2015) 192 final (May 6, 2015), at § 3.3 [hereinafter Digital Single Market Strategy].

${ }^{5}$ Id. (citing Jean-Claude Juncker, Political Guidelines for the Next European Commission-A New Start for Europe: My Agenda for Jobs, Growth, Fairness and Democratic Change (July 15, 2014)).

${ }^{6}$ See Priority: Digital Single Market, EUROPEAN COMM'N, http:/ec.europa.eu/priorities/digitalsingle-market_en [https://perma.cc/G8LU-A5JN] (last visited June 3, 2017).

${ }^{7}$ See Proposal for a Regulation of the European Parliament and of the Council on Addressing Geo-Blocking and Other Forms of Discrimination Based on Customers' Nationality, Place of Residence or Place of Establishment Within the Internal Market and Amending Regulation (EC) No. 2006/2004 and Directive 2009/22/EC, COM (2016) 289 final (May 25, 2016).

8 Digital Single Market Strategy, supra note 4, at $\S \S 2.1-4,3.3$.

9 Digital Single Market Strategy, supra note 4, at $\$ 2.4$ (emphasis added).
} 
dealing with unlawful third-party content. ${ }^{10}$ These enhanced responsibilities would apply when intermediaries deal with illegal content, such as child pornography, terrorist materials, and content that infringes upon intellectual property rights. ${ }^{11}$ In particular, the Commission is discussing what regulations should apply to a subset of those intermediaries deemed "online platforms" and "whether to require intermediaries to exercise greater responsibility and due diligence in the way they manage their networks and systems - a duty of care." 12 It is worth noting that some European national jurisdictions are already in the process of implementing some form of a "duty of care."13 The German coalition agreement, for example, emphasized that "internet service providers should take more responsibility" for mass copyright infringement. ${ }^{14}$ Specifically, the German coalition plans to "improve enforcement in particular towards platforms whose business model is mainly based on the infringement of copyright" by ensuring "that such service providers no longer enjoy the general liability privilege as so-called hosting provider and in particular no longer receive advertising revenues." 15

The DSMS was followed by a number of other actions to bring Europe up to speed in the digital market. Some of these actions are especially relevant for intermediary liability. First, the Commission released a new Communication, Towards a Modern, More European Copyright Framework, ${ }^{16}$ anticipating that policy and legislative action would be taken in respect to: (1) exceptions to digital and cross-borders environments; ${ }^{17}$ (2) exclusive rights, including both clarifying issues facing linking to other content and considering whether any action specific to

${ }^{10} I d$. at $\S \S 3.3 .1-2$.

11 Id. at $\S 3.3 .2$.

12 Id.

13 See eCommerce Directive, supra note 2, at Recital 48, (establishing that "[t]his Directive does not affect the possibility for Member States of requiring service providers, who host information provided by recipients of their service, to apply duties of care, which can reasonably be expected from them and which are specified by national law, in order to detect and prevent certain types of illegal activities") (emphasis added).

${ }^{14}$ See Deutschlands Zukunft gestalten - Koalitionsvertrag zwischen CDU, CSU und SPD, 18 Legislaturperiode (December 17, 2013), 133-34, http://www.bundesregierung.de/Content/DE/ _Anlagen/2013/2013-12-17-koalitionsvertrag.pdf

${ }^{15} I d$. at 133 .

${ }^{16}$ See Communication from the Commission to the European Parliament, the Council, the European Economic and Social Committee and the Committee of the Regions: Towards a Modern, More European Copyright Framework, COM (2015) 260 final (Dec. 9, 2015).

${ }^{17}$ Id. at 6-9; see also Proposal for a Regulation of the European Parliament and of the Council, on Ensuring the Cross-Border Portability of Online Content Services in the Internal Market, COM (2015) 627 final (Dec. 9, 2015). 
news aggregators is needed; ${ }^{18}$ and (3) enforcement, including "follow the money" strategies, commercial-scale infringements, application of provisional and precautionary measures, injunctions and their cross-border effect, notice and action mechanisms, and the "take down and stay down" principle. ${ }^{19}$

Meanwhile, the Commission also launched a "public consultation on the evaluation and modernization of the legal framework for the enforcement of intellectual property rights. ${ }^{20}$ This consultation discusses reform within the DSMS that will affect liability of online intermediaries. Provisions established by the Enforcement Directive on topics including legal action, the right of information, damages and costs, and provisional and precautionary measures might soon be revisited. ${ }^{21}$ In particular, injunctions against online intermediaries might be considered in the next round of reforms. European law might be amended by explicitly establishing that all types of intermediaries can be enjoined and no specific intermediaries' liability or violation of any duty of care would be required to issue an injunction. ${ }^{22}$ Apparently, the Commission might also like to clarify or update the European Court of Justice's position in Telekabel. ${ }^{23}$ First, the Commission might introduce criteria for defining the proportionality of an injunction. ${ }^{24}$ Additionally, the Enforcement Directive might be amended to "clarif[y]... how to balance the effective implementation" of enforcement measures and users' "right to freedom of information" in case of a blocking order that does not specify the measures that a service provider must take. ${ }^{25}$

\footnotetext{
18 Towards a Modern, More European Copyright Framework, supra note 16, at 9-10.

${ }^{19}$ Id. at 10-11; see also Annemarie Bridy, Internet Payment Blockades, 67 FLA. L. REV. 1523 (2015).

${ }^{20}$ See Public Consultation on the Evaluation and Modernization of the Legal Framework for IPR Enforcement: Summary of Responses, EUROPEAN COMM'N (Sept. 14, 2016) [hereinafter Commission].

${ }^{21}$ See Corrigendum to Directive 2004/48/EC of the European Parliament and of the Council of 29 April 2004 on the Enforcement of Intellectual Property Rights, 2004 O.J. (L 195) 16, $16-17$ [hereinafter Enforcement Directive].

22 See Commission, supra note 20, at 36.

23 See Case C-314/12, UPC Telekabel Wien GmbH v. Constantin Film Verleih GmbH and Wega Filmproducktionsgesellschaft mbH, 2014 E.C.R. 192 (Mar. 27, 2014) (stating that EU law does not preclude a court "injunction [that] does not specify the measures which that access provider must take" to block access to a copyright-infringing website).

${ }^{24}$ See Commission, supra note 20, at 36-37.

${ }^{25} I$ d. at 36.
} 


\section{UNCHANGED INTERMEDIARY LIABILITY REGIME? THE DEVIL IS IN THE SECTORIAL LEGISLATION AND VOLUNTARY MEASURES}

The Commission also launched a public consultation on the role and responsibilities of online intermediaries and platforms. ${ }^{26}$ The consultation raised a number of pointed questions about the intermediary liability framework in the EU. ${ }^{27}$ In particular, Section 3 of the Consultation, Tackling Illegal Content Online and the Liability of Online Intermediaries, questioned whether the eCommerce Directive's reference to "mere technical, automatic and passive" activity by intermediaries is sufficiently clear, ${ }^{28}$ whether additional categories of intermediaries should be established; ${ }^{29}$ whether particular types of content merit different notice-andaction procedures; ${ }^{30}$ whether action should include "take down and stay down" or prospective monitoring for flagged content; ${ }^{31}$ and whether there should be imposed specific duties of care for certain intermediaries. ${ }^{32}$

"A consensus emerged from the consultation" that the "existing liability principles on which the Section IV of the E-Commerce Directive is based are fit-for-purpose." 33 Therefore, the Commission published a communication, Online Platforms and the Digital Single Market, which apparently endorses maintaining the existing intermediary liability regime. ${ }^{34}$ However, this broad programmatic statement might be deceiving. As usual, the devil is in the details. The Commission did stress that "a number of specific issues relating to illegal and harmful content and activities online have been identified that need to be addressed," ${ }^{35}$ which

\footnotetext{
${ }^{26}$ See QueStionNaire, Regulatory ENVIRONMENT FOR PlatForms, ONLINE INTERMEDIARIES, Data and Cloud Computing and the Collaborative Economy, European Comm'n; Public Consultation on the Regulatory Environment for Platforms, Online Intermediaries, Data and Cloud Computing and the Collaborative Economy, EUROPEAN COMM'N (Sept. 24, 2015), https://ec.europa.eu/ digital-single-market/news/public-consultation-regulatory-environment-platforms-onlineintermediaries-data-and-cloud [https://perma.cc/D43H-36ZC].

27 QUeSTIONNAIRE, supra note 26, at 5.

${ }^{28}$ Id. at 17, 19; see also eCommerce Directive, supra note 2, at Recital 42.

${ }^{29}$ QUESTIONNAIRE, supra note 26, at 19.

30 Id. at $19-21$.

31 Id. at $20-21$.

${ }^{32} I d$. at $21-23$.

33 See Full Report on the Results of the Public Consultation on the Regulatory Environment for Platforms, Online Intermediaries and the Collaborative Economy, EUROPEAN COMM'N (May 25, 2016), https:/ec.europa.eu/digital-single-market/en/news/full-report-results-public-consultationregulatory-environment-platforms-online-intermediaries [https://perma.cc/5UJ2-RANY].

${ }^{34}$ See Communication from the Commission to the European Parliament, the Council, and the European Economic and Social Committee, and the Committee of the Regions, Online Platforms and the Digital Single Market: Opportunities and Challenges for Europe, COM (2016) 288 final, at 9 (May $25,2016)$ [hereinafter OP\&DSM Communication].

${ }^{35}$ Id. at 8 .
} 
suggests that online intermediaries' liability relating to certain categories of illegal content could be expanded.

In light of the Commission's conclusion that the current liability regime is generally adequate, but specific problems still need to be addressed, the Commission suggested a "sectorial, problem-driven approach" 36 that implements different policy approaches for different categories of illegal content. Apparently, this sectorial action will target copyright-protected content, minors' protection from harmful content, and incitement through hatred. ${ }^{37}$ In other words, according to the Commission, intermediary liability should be expanded by imposing an obligation on online platforms to behave responsibly by addressing specific contentrelated problems.

The Commission recommends addressing these content-specific issues with a mix of legislative interventions - by updating the audio-visual and copyright regulations - and voluntary self-regulatory actions. ${ }^{38}$ The Commission specifically encouraged immediate self-regulatory efforts by online intermediaries that are designed to fight incitement to terrorism and prevent hate speech. ${ }^{39}$ The $O P \& D S M$ Communication puts forward the idea that the responsibility of online platforms is "wid[ening]" and has become a key, cross-cutting issue. ${ }^{40}$ In doing so, the Commission has endorsed a strategy that shifts the policy approach from intermediary liability to intermediary responsibility, with special emphasis on voluntary measures from intermediaries to curb undesired conduct—and speech — online. As an immediate result of this new policy trend, the Commission recently agreed with all major online hosting providers-including Facebook, Twitter, YouTube, and Microsoft- on a "code of conduct that includes a series of commitments to combat the spread of illegal hate speech online in Europe." ${ }^{41}$ Apparently, the Commission aligns its strategy for online platforms to a globalized, ongoing movement towards privatization of law enforcement online through algorithmic tools. ${ }^{42}$

\footnotetext{
36 See id. at 9 .

37 Id. at $8-9$.

38 Id. at 9.

39 Id. at $8-9$.

${ }^{40} I d$. at $7-9$.

41 See European Commission Press Release IP/16/1937, European Commission and IT Companies Announce Code of Conduct on Illegal Online Hate Speech (May 31, 2016); Fighting Illegal Online Hate Speech: First Assessment of the New Code of Conduct, European COMM'N (Dec. 6, 2016), ec.europa.eu/newsroom/just/item-detail.cfm?item_id=50840 (urging platforms to do more to implement the code of conduct) [https://perma.cc/Y6AM-SP9L].

${ }^{42}$ See Joe McNamee, Leaked EU Communication-Part 1: Privatized Censorship and Surveillance, EDRI (Apr. 27, 2016), https://edri.org/leaked-eu-communication-privatised-censorshipand-surveillance [https://perma.cc/UFV8-Q4RB].
} 
Despite their focus on voluntary intermediary self-regulation, the Commission's proposals do include an important role for legislative intervention. In particular, the Commission proposes updating the AudioVisual Media Services Directive to address the proliferation of hate speech and content that is harmful to minors on online video sharing platforms ${ }^{43}$ This sector-specific regulation would require platforms to put in place measures to protect minors from harmful content and to protect everyone from incitement to hatred. ${ }^{44}$ Commentators have been concerned that the AVMS revision might erode the eCommerce Directive "no monitoring obligations" for video platforms-especially if the "harmful" content category is to be interpreted more broadly than "illegal" content. ${ }^{45}$ Therefore, the AVMS Draft revision also represents an expansion of intermediary liability.

\section{Copyright In the Digital Single Market: Closing the VAlue GAP?}

The Communication also suggested promoting a fairer allocation of value generated by the distribution of copyright-protected content online. ${ }^{46}$ The Commission presented its suggestion for a platform-sensitive update of EU copyright policy in a proposal for a directive on copyright in the Digital Single Market. ${ }^{47}$ This draft directive is part of a larger package aimed at modernizing EU copyright rules and achieving a fully functioning Digital Single Market.

The draft directive aims, inter alia, to close the so-called "value gap" between internet platforms and copyright holders. The idea of a "value gap" echoes a discourse almost exclusively fabricated by the music and entertainment industry. Apparently, this rhetorical device was coined for

\footnotetext{
43 See Proposal for a Directive of the European Parliament and of the Council Amending Directive 2010/13/EU on the Coordination of Certain Provisions Laid Down by Law, Regulation or Administrative Action in Member States Concerning the Provision of Audiovisual Media Services in View of Changing Market Realities, COM (2016) 287 final (May 25, 2016) [hereinafter AVMS Draft] (discussing these issues broadly in the "Explanatory Memorandum").

44 Id. at Art. 6 \& 28.

45 See Daphne Keller, Can a New Broadcasting Law in Europe Make Internet Host Monitor Their Users?, CIS BLOG (May 27, 2016, 2:51 PM), https://cyberlaw.stanford.edu/blog/2016/05/can-newbroadcasting-law-europe-make-internet-hosts-monitor-their-users [https://perma.cc/8H3H-EWRK]; see also AVMS Draft, supra note 43, at Art. 6

46 OP\&DSM Communication, supra note 34, at 8 (emphasis added).

47 Proposal for a Directive of the European Parliament and of the Council on Copyright in the Digital Single Market, COM (2016) 593 final (Sept. 14, 2016), 1, Art. 13 [hereinafter DSM Directive Proposal].
} 
the first time in music industry global reports. ${ }^{48}$ After unsuccessful attempts to seek judicial redress against user-generated content platforms ("UGC platforms"), ${ }^{49}$ the industry decided to plead its case before the legislators and seek legislative reform. ${ }^{50}$ Rightholders complained that the lawspecifically liability exemptions for UGC platforms, the lack of monitoring obligations, and the notice and take-down regime-left them with no ability to monetize the exchange of protected content on UGC platforms. Rightholders suggested that, rather than entering into licensing agreements, UGC platforms should offer to remove infringing content upon notice or possibly implement voluntary measures like YouTube's Content ID. ${ }^{51}$ As a result, other platforms whose primary business is to sell content to usersand therefore do not qualify for liability exemptions and must license copyrights from rightholders - would be willing to pay less in licensing fees in order to remain competitive with UGC platforms. Recently, the same rhetoric has been redeployed in the United States. In an open letter to President-elect Donald Trump, the music industry sought reform of safe harbor legislation, pointing out that high-tech companies have thrived on free music and the "value grab." 52

There are two major problems with this "value-grab" rhetoric. First, it echoes an overexploited narrative identifying the internet as a digital threat rather than a digital opportunity. ${ }^{53}$ These narratives undervalue the opportunities that the internet, digitization, and sharing economies provide for creators. The other major problem with this rhetoric is that it is scarcely supported by empirical evidence. The Draft Directive's Impact Assessment admits this by noting that "economic impacts are mostly assessed from a qualitative point of view" and that no quantitative analysis of the impacts

48 See Martin Husovec, EC Proposes Stay-down \& Expanded Obligation to License UGC Services, HUT'KO'S TECH. LAW BLOG, (Sept. 1, 2016), http://www.husovec.eu/2016/09/ec-proposes-stay-downexpanded.html [https://perma.cc/CYG5-LZF9].

49 See, e.g., Rechtsprechung der Oberlandesgericht in München [OLG] [Higher Regional Court], 29 U 2798/15 Jan. 28, 2016 (Ger.) (ruling against GEMA, a performers' rights organization in Germany, in holding that YouTube could not be held liable for damages for hosting copyrighted content without the copyright holder's permission).

50 See, e.g., Press Release, GEMA, EU Copyright Modernisation: First Steps Towards a Fair and Balanced Relationship Between Authors \& Online Platforms (Sept. 14, 2016), https://www.gema.de/ en/aktuelles/eu_urheberrechtsreform_erste_schritte_zu_einem_fairen_ausgleich_zwischen_urhebern_un d_online_plattf [https://perma.cc/5K8H-LFBR].

51 See How Content ID Works, YouTUBE HeLP, https://support.google.com/youtube/answer/ 2797370?hl=en [https://perma.cc/AJ5P-RJZF] (last visited June 5, 2017).

52 See Letter from Am. Ass'n of Indep. Music et al. to Donald J. Trump, President-Elect of the United States (Dec.13, 2016) http://www.riaa.com/wp-content/uploads/2016/12/Letter-to-POTUSEfrom-Music-Community-121316.pdf [https://perma.cc/U6EM-597U].

53 See James Boyle, The Public Domain: Enclosing the Commons of the Mind 54-82 (Yale University Press 2008). 
of the different policy options was undertaken because of "[t]he limited availability of data in this area." 54 The European Copyright Society reinforced this point by stating that they "are disappointed to see that the proposals are not grounded in any solid scientific (in particular, economic) evidence." 55 In reality, there is no clear evidence on the scale, nature, or effects of copyright infringement in the digital environment, or the effectiveness of more aggressive enforcement strategies. In an authoritative report commissioned by the UK government, Professor Ian Hargreaves noted the major problem with this lack of empirical evidence: that copyright policies should be based on hard and transparent evidence, and so far none has been provided. ${ }^{56}$

Professor Hargreaves is correct: in crafting the European Digital Single Market Strategy, clear empirical evidence should have been carefully reviewed to consider whether creators and the creative market as a whole have been withering or flourishing. So far, independent empirical evidence supporting the present enforcement strategy has never been provided. Also never considered was contrary evidence that might emphasize positive externalities for creativity of the internet, digitization, and platform economy. This contrary evidence is plentiful. The literature has consistently shown that, in reality, the digital platform economy has created value for content providers, not a value gap that needs to be closed. ${ }^{57}$ Empirical studies have shown that in the digital environment, "the sky is rising," rather than falling, as far as creative industries are concerned. ${ }^{58}$ Piracy has forced the market to adapt to user needs, ${ }^{59}$ and the market has in fact adapted by offering new and more affordable ways to

\footnotetext{
54 European Commission, Commission Staff Working Document, Impact Assessment on the Modernisation of EU Copyright Rules, 136, SWD (2016) 301 final PART 1/3 (Sept. 14, 2016).

55 European Copyright Society, General Opinion on the EU Copyright Reform Package (January 24, 2017), 5, https://europeancopyrightsocietydotorg.files.wordpress.com/2015/12/ecs-opinion-on-eucopyright-reform-def.pdf.

56 See IAn Hargreaves, Digital OpPoRtunity: A Review of Intellectual Property AND GROWTH 10 (2011) (emphasis added); see also Joe Karaganis, Rethinking Piracy, in MEDIA PIRACY IN EMERGING ECONOMIES 4, 4-11 (Joe Karaganis ed., 2011) (making the same point).

${ }^{57}$ See Giancarlo F. Frosio, Digital Piracy Debunked: A Short Note on Digital Threats and Intermediary Liability, INTERNET POL'Y REV., Mar. 2016, at 1-22 (discussing in details the empirical studies cited below).

${ }^{58}$ See Michael Masnick and Michael Ho, Floor 64, The Sky is Rising: A Detailed Look AT the State of the EnTERTAinmENT IndUStRy 3 (2012); see also Joel Waldfogel, Is the Sky Falling? The Quality of New Recorded Music Since Napster, Vox (Nov. 14, 2011), http://www.voxeu.org/index.php?q=node/ 7274_[https://perma.cc/2HJU-LW56].

59 See generally ADRIAN JOHNS, PIRACY: THE INTELLECTUAL PROPERTY WARS FROM GUTENBERG to GAtes (U. of Chicago Press 2009).
} 
enjoy creativity. ${ }^{60}$ This narrative, and empirical economic studies that support it, are nowhere to be found in the impact assessment justifying the draft directive or in the larger institutional debate surrounding it.

\section{A. Ancillary Rights for Publishers}

A groundbreaking provision aimed at closing the value gap - and affecting directly online intermediaries - is the introduction of a neighboring right for press publishers for the digital uses of their publication. ${ }^{61}$ This new sui generis right would last for twenty years from the date of the publication. ${ }^{62}$ It would also apply retroactively to press publications already published. ${ }^{63}$

Allegedly, the introduction of this neighboring right for press publishers is based on the assumption that "[i]n the transition from print to digital, publishers of press publications are facing problems in licensing the online use of their publications and recouping their investments." ${ }^{64}$ According to the Impact Assessment, without this right, press publishers would curb their investment in the digital press publishing market due to complex and inefficient licensing and enforcement in the digital environment. ${ }^{65}$ However, the Impact Assessment does not provide any evidence to support this conclusion. ${ }^{66}$ Also, in advance of the Directive proposal, several leading European scholars have already advised against the introduction of any neighboring rights for publishers, making arguments based on empirical effects on market efficiency. ${ }^{67}$ To put it

${ }^{60}$ See CREATe Copyright ReSEarch Ctr., Univ. of Glasgow, Copyright Evidence, COPYRIGHT EVIDENCE WIKI (Nov. 14, 2016, 2:33 PM), http://www.copyrightevidence.org [https://perma.cc/KPG9-NFB8] (trying to establish a body of evidence that allows better decisionmaking in the contested copyright policy field).

${ }^{61}$ See DSM Directive Proposal, supra note 47, Art. 11 (providing "publishers of press publications with the rights" of reproduction and making them available to the public "for the digital use of their press publications").

${ }^{62} I d$. Neighboring rights — or related rights - are characterized by the fact that they are created for rightholders' categories that are not technically authors and might share only some of the requirements of traditional copyright and have a different scope of protection.

${ }^{63}$ DSM Directive Proposal, supra note 47, Art. 18.

${ }^{64} I d$.

65 See Commission Staff Working Document, Impact Assessment on the Modernisation of EU Copyright Rules, at 175-92, SWD (2016) 301 final, PART 3/3 (Sept. 14, 2016) [hereinafter Impact Assessment]; DSM Directive Proposal, supra note 47, at 18-19.

${ }^{66}$ See Impact Assessment, supra note 65, at 175-92.

${ }^{67}$ See Martin Kretschmer, Séverine Dusollier, Christophe Geiger \& P. Bernt Hugenholtz, The European Commission's Public Consultation on the Role of Publishers in the Copyright Value Chain: A Response by the European Copyright Society, 38 European InTELleCtual ProP. ReV. 591, 591595 (2016), https://papers.ssrn.com/sol3/papers.cfm?abstract_id=2801595 [https://perma.cc/63QBSH3D]; Reto M. Hilty, Kaya KöKLÜ \& Valentina Moscon, Position Statement of the MaX 
bluntly, the causality between the demise of traditional press publishing and the growth of new information society services, such as online news aggregators - and hence the need for granting new neighboring rightswas never shown. ${ }^{68}$ Apparently, this reform is also based on a marketingdriven, industry-led narrative, rather than empirical evidence showing a causal link between inefficiencies in the market and the legal instruments proposed.

This proposal follows in the footsteps of press publishers' rights created by a limited number of Member States. Similar arrangements enacted in Spain and Germany already stirred up quite a debate.$^{69}$ Empirical evidence collected after the enactment of these neighboring rights showed that the reforms were ineffective and altogether detrimental. In Germany, the law did not achieve the desired results. ${ }^{70}$ Actually, German press publishers authorized Google to index their publications and feature them in Google's news and search services free of charge. ${ }^{71}$ Some smaller news aggregation services operating in Germany delisted press publishers or stopped using snippets. ${ }^{72}$ In Spain, the adoption of the law also led to unexpected results. ${ }^{73}$ First, Google shut down its Spanish Google News service. In addition, recent empirical evidence confirmed that news aggregators had a positive effect on online news sites in Spain, which

Planck InStitute for InNOvation and Competition on the "Public Consultation on the Role OF Publishers IN THE COPYRight VAlue ChaiN” (2016), http://pubman.mpdl.mpg.de/ pubman/item/escidoc:2321286:3/component/escidoc:2436801/MPI_Position_statement_15_6_2016_de f.pdf [https://perma.cc/AJ3W-UY9S]; Eleonora Rosati, Neighbouring Rights for Publishers: Are National and (Possible) EU Initiatives Lawful?, 47 INT'L REV. INTELLECTUAL PROP. \& COMPETITION L. 569, 571, 585 (2016); Alexander Peukert, An EU Related Right for Press Publishers Concerning Digital Uses. A Legal Analysis §§ 5-13 (Goethe Univ. Frankfurt am Main Research Paper No. 22/2016, 2016), https://www.eco.de/wp-content/blogs.dir/copyright_-legal-analysis.pdf [https://perma.cc/RL5J9RQM].

${ }^{68}$ See Susana Navas Navarro, Periódicos Digitales y Agregadores de Contenido Informativo en España [Digital Newspapers and Aggregators of News Content in Spain], 246 Revue Internationale du Droit d'Auteur 72, 120-25 (2015).

${ }^{69}$ See Christophe Geiger, Oleksandr Bulayenko \& Giancarlo Frosio, Opinion of the CEIPI on the European Commission's Copyright Reform Proposal with a Focus on the Introduction of Neighbouring Rights for Press Publishers in EU Law 5-8 (Ctr. for Int'l Intellectual Prop. Stud. Research Paper No. 2016-01, 2016), https://papers.ssrn.com/sol3/papers.cfm?abstract_id=2921334 [https://perma.cc/UXN2NWLV] (reviewing these national legislations).

${ }^{70}$ See Andreas Becker, German Publishers Vs. Google, DeUTSCHE Welle, (Oct. 30, 2014), http://www.dw.com/en/german-publishers-vs-google/a-18030444 [https://perma.cc/K2QA-F6LN]; Raquel Xalabarder, Press Publisher Rights in the New Copyright in the Digital Single Market Draft Directive 16-17 (Ctr. for Copyright \& New Bus. Models Creative Econ. Working Paper 2016/15, 2016), http://www.create.ac.uk/publications/press-publisher-rights-in-the-new-copyright-in-the-digitalsingle-market-draft-directive/ [https://perma.cc/P85B-M2QQ]

${ }^{71} I d$.

72 See Kretschmer, Dusollier, Geiger \& Hugenholtz, supra note 67, at 594.

73 See Xalabarder, supra note 70, at 17-21. 
directly contradicts the predictions in the Impact Assessment and the Directive Proposal. ${ }^{74}$ The study found that in the first three months of 2015, the closing of Google News and a number of smaller news aggregation services led to a decline of more than six percent of internet traffic to Spanish newspapers. ${ }^{75}$ Because news aggregators have a "market expansion effect," "76 the closing of the news aggregators particularly hurt small publications by decreasing the number of new visitors to their sites. ${ }^{77}$ It also created barriers to innovation for other information intermediaries that compile customized services based on users' online activities or aggregate content for mobile phones, as well as algorithmic aggregators designed to deliver dynamic content. ${ }^{78}$

These findings show troubling potential negative externalities of the reform, especially in terms of access to information (and therefore democratization) and innovation policy. First, the proposal might negatively impact smaller publishers, and therefore promote a recentralization of online news outlets. This would detract from the diversity of information on the internet, limit users' access to information, and hinder democratization..$^{79}$ The literature explaining why centralization hinders democratization is plentiful. ${ }^{80}$ As Jerome Barron argued, a democratic system should aim to decentralize information. ${ }^{81}$ In general, concentrated systems are likely to exclude challenges to prevailing wisdom $^{82}$ and translate unequal distribution of economic power into

\footnotetext{
74 See Pedro Posada de la Concha, Alberto Gutiérrez García \& Hugo Hernández Cobos, NERA Econ. Consulting, Impacto del Nuevo Artículo 32.2 DE LA Ley de Propiedad Intelectual: INFORME PARA LA ASOCIACIÓN ESPAÑOla DE EDITORIALES DE PUbliCACIONES PERIÓDiCAS (AEEPP)

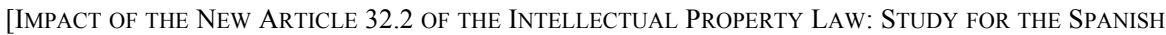
Association of Publishers of Periodical Publications], at xiii (2015), http://www.aeepp.com/ pdf/InformeNera.pdf [https://perma.cc/BH2L-XHV3].

75 Id. at xii.

76 The phrase "market expansion effect" refers to the ability of news aggregators to drive visitors to news websites who would otherwise not have visited those websites. Id. at $\mathrm{x}$.

77 Id. at xiv.

${ }^{78} I d$. at xii.

${ }^{79}$ See Peukert, supra note 67 , at $\S \S 186-94$.

80 See Jerome A. Barron, Access to the Press-A New First Amendment Right, 80 HARV. L. ReV. 1641 (1967) [hereinafter Barron, Access to the Press]; Jerome A. Barron, Access-The Only Choice for the Media?, 48 TEX. L. REV. 766 (1970) [hereinafter Barron, The Only Choice]; see also Neil Weinstock Netanel, New Media in Old Bottles? Barron's Contextual First Amendment and Copyright in the Digital Age, 76 GeO. WASH. L. REV. 952 (2008); Yochai Benkler, A Speakers' Corner Under the Sun, in THE COMmOdificATION OF INFORMATION 291 (Niva Elkin-Koren \& Neil Weinstock Netanel eds., 2002).

${ }^{81}$ See Barron, The Only Choice, supra note 80.

82 See Barron, Access to the Press, supra note 80, at 1641-47.
} 
unequal distribution of power to express ideas. ${ }^{83}$ Media concentration creates disparities in the ability to be heard ${ }^{84} \mathrm{~A}$ study on the state of the implementation of the UNESCO Convention on the Protection and Promotion of the Diversity of Cultural Expressions ${ }^{85}$ in Europe noted that, while some copyright is necessary, too much copyright is detrimental to diversity of cultural expression. ${ }^{86}$ Diversity of cultural expression is particularly threatened by intellectual property rights "in markets that are dominated by big corporations exercising collective power as oligopolies." ${ }^{87}$ This process of concentration endangers cultural diversity in that "a handful-six to ten vertically integrated communications companies - will soon produce, own, and distribute the bulk of the culture and information circulating in the global marketplace." ${ }^{88}$

Second, the creation of new neighboring rights enjoying retroactive effects would remove material from the public domain and consequently impinge freedom of expression and democratization. ${ }^{89}$ The enclosure of the public domain enhances centralized media's market power, while proportionally disincentivizing decentralization. The public domain is a metaphysical public forum that "belong[s] to everyone, because [it] belong[s] to no one, from which people cannot be excluded on the grounds that a property owner wishes to exclude them." 90 Thus, "[t]he public

${ }^{83}$ See Owen M. Fiss, Free Speech and Social Structure, 71 IOwA L. REV. 1405, 1412-13 (1986); J.M. Balkin, Some Realism About Pluralism: Legal Realist Approaches to the First Amendment, 1990 DuKE L.J. 375, 404-12 (1990).

${ }^{84}$ See Neil Weinstock Netanel, Copyright and a Democratic Civil Society, 106 YALE L.J. 283, 362 (1996); Neil Weinstock Netanel, Market Hierarchy and Copyright in Our System of Free Expression, 53 Vand. L. ReV. 1879, 1879-82 (2000); Neil Weinstock Netanel, Copyright and 'Market Power' in the Marketplace of Ideas, in ANTITRUST, PATENTS AND COPYRIGHT 149, 160-62 (François Lévêque \& Howard Shelanski eds., 2005); see also Christopher S. Yoo, Copyright and Democracy: A Cautionary Note, 53 VAND. L. REV. 1933 (2000).

${ }^{85}$ See U.N. Educ., Sci. \& Cultural Org., Convention on the Protection and Promotion OF THE DIVERSITY OF CULTURAL EXPRESSIONS (2005).

${ }^{86}$ GERMANN AVOCATS, IMPLEMENTING THE UNESCO CONVENTION OF 2005 IN THE EUROPEAN UNION 26, 76-78 (2010), http://www.diversitystudy.eu/ms/ep_study_long_version_20_nov_2010_ final.pdf [https://perma.cc/D4BS-H38Y] (study prepared for the European Parliament).

${ }^{87}$ Id. at 26

88 Ronald V. Bettig, Copyrighting Culture: The Political Economy of Intellectual PROPERTY 38 (1996).

${ }^{89}$ For a discussion of the negative effects of the enclosure of the public domain for European citizens, see Giancarlo F. Frosio, COMmunia, COMMUNiA Final Report (2011), http://nexa.polito.it/nexacenterfiles/D1.11-COMMUNIA\%20Final\%20Report-nov2011.pdf [https://perma.cc/KS3U-99HC] (report prepared for the European Commission on behalf of the COMMUNIA Network and the NEXA Center); see also Xalabarder, supra note 70, at 22-24 (noting that this proposal completely upsets the dichotomy between unprotected information and protected expressions embedded in copyright law)

${ }^{90}$ Rebecca Tushnet, Domain and Forum: Public Space, Public Freedom, 30 COLUM. J.L. \& ARTS 597, 598 (2007). 
domain represents our free speech concerns within the realm of copyright law." ${ }^{11}$ Consequently, any increase or decrease in the public domain will proportionally affect our freedom of speech.

In addition, the public domain promotes rich and diverse expressions regardless of the market power of the speakers, as there are no costs inherent in utilizing the public domain. Any decrease in the public domain will produce the most direct repercussions on people with less ability to finance the dissemination of their speech. Copyright expansion favors organizations that own large information inventories over smaller organizations and individuals who will have to buy access to the information that is removed from the public domain.92 Thus, any contraction of the public domain will work against the goal of bringing "the millions of dispossessed and disadvantaged... in from the margins of society, and cultural policy in from the margins of governance." ${ }^{93}$

These consequences are especially likely to follow from the removal of information from the online public marketplace, as the internet is "a driver of greater pluralism in the media, giving both access to a wider range of sources and points of view as well as the means for individuals-who might otherwise be denied the opportunity - to express themselves fully and openly." 94 The internet changed freedom of expression's focus from the right of a few privileged speakers to address the masses to the right of each person to participate in a "democratic culture." 95

Third, introducing neighboring rights for press publishers would act as a strong disincentive for innovators, as it would back up property owners' attempts to leverage their holdout power to block progress. Anticompetitive behaviors are common in this context, and property owners repeatedly try

91 Michael D. Birnhack, More or Better? Shaping the Public Domain, in THE FUTURE OF THE Public Domain: IDENTIFYING THE COMMONS IN INFORMATION LAW 59, 62 (Lucie Guibault \& P. Bernt Hugenholtz eds., 2006); see also Yochai Benkler, Free as the Air to Common Use: First Amendment Constraints on Enclosure of the Public Domain, 74 N.Y.U. L. REV. 354, 393 (1999).

${ }^{92}$ Yochai Benkler, A Political Economy of the Public Domain: Markets in Information Goods vs. The Marketplace of Ideas, in EXPANDING THE BOUNDARIES OF INTELLECTUAL PROPERTY: INNOVATION POLICY FOR THE KNOWLEDGE SOCIETy 267, 273-74 (Rochelle C. Dreyfuss, Diane Leenheer Zimmerman \& Harry First eds., 2001).

93 European TASK Force On Culture \& DEV., In From the MARGins: A CONTRIBUtion to THE Debate on Culture AND Development in Europe 7 (1997) (report prepared for the Council of Europe).

94 Commission Communication from the Commission to the European Parliament, the Council, the European Economic and Social Committee, and the Committee of the Regions: A Digital Agenda for Europe, at 30, COM (2010) 245 final (May 19, 2010).

95 See Jack M. Balkin, Digital Speech and Democratic Culture: A Theory of Freedom of Expression for the Information Society, 79 N.Y.U. L. REV. 1, 1 (2004) (arguing that digital technologies should change the focus of free speech theory from a concern for protecting democratic process to a larger concern promoting and protecting a democratic culture). 
to leverage their holdout power. This behavior applies to property at large ${ }^{96}$ but it surfaced often throughout the history of copyright in particular. ${ }^{97}$ This time, innovators will be disincentivized from developing technologies that compile and aggregate content on the internet.

Finally, an additional point should be stressed in connection with the overall scope of this reform process. Ancillary rights to press publication for online uses would delay, rather than promote, the Digital Single Market. The introduction of an additional layer of twenty-eight national rights would certainly lead to further challenges related to fragmentation and territoriality of rights. ${ }^{98}$ In addition, as there is already no uniform approach to exceptions or limitations to twenty-eight national authors' rights - which has led to considerable uncertainty in that area of the lawallowing the creation of twenty-eight additional national rights for publishers would have the same result, which is exactly what the Digital Single Market is designed to avoid. ${ }^{99}$

\section{B. Platforms'Revenue-Share Agreements and Filtering}

The proposed reform also includes a second provision that would impact platform operations broadly. It requires intermediaries "that store and provide to the public access to large amounts of works ... uploaded by their users" to take appropriate and proportionate "measures to [either] ensure the functioning of agreements concluded with rightholders for the use of their works" or "prevent the availability on their services of [such] works," including through "the use of effective content recognition technologies." ${ }^{100}$ Put bluntly, under this provision, UGC platforms would have to shoulder more responsibility for rooting out infringements and share revenues with creators.

The scope of the provision is still to be determined. In particular, Recital 38(1-2) of the proposal - read together with Article 13-might cause some interpretive headaches. ${ }^{101}$ Apparently, the new proposal would

\footnotetext{
${ }^{96}$ See Carol Rose, The Comedy of the Commons: Custom, Commerce, and Inherently Public Property, 53 U. CHI. L. REV. 711, 749-50, 752 (1986) (discussing how large public projects such as highways or railroads are vulnerable to the holdout power of single property owners).

97 See Hannibal Travis, Building Universal Digital Libraries: An Agenda for Copyright Reform, 33 PEPP. L. REV. 761, 786-92 (2006) (sketching a quick history of holdouts on cultural technological advancements); see also Giancarlo F. Frosio, Google Books Rejected: Taking the Orphans to the Digital Public Library of Alexandria, 28 SANTA ClaRA COMPUTER \& High TeCH. L.J. 81, 128-130 (2011) (reviewing the relevant case law).

98 See Geiger, Bulayenko \& Frosio, supra note 69, at 8.

99 Id., at 9-10.

${ }^{100}$ DSM Directive Proposal, supra note 47, at Art. 13, cl. 1.

101 Id., at $1-5$.
} 
apply to active hosting providers. The proposal refers only to those who "store and provide access" to protected works, which restricts the proposal's scope to hosting providers. ${ }^{102}$ If a hosting provider is not eligible for the liability exemption established by Article 14 of the eCommerce Directive, it is obliged to enter into licensing agreements with rightholders. ${ }^{103}$ For the Article 14 exemption not to apply, a hosting provider must "play an active role." ${ }^{104}$ In defining a hosting provider that plays an active role, Recital 38 of the proposal states that it must go "beyond the mere provision of physical facilities." 105 Redeploying the language from L'Oréal $v$. eBay, the proposal notes that playing an active role "includ[es] . . . optimising the presentation of the uploaded works or subject-matter or promoting them, irrespective of the nature of the means used therefor." ${ }^{106}$ By referring to L'Oréal, the proposal might also imply that a hosting provider can still be protected even if it is not completely passive as long as it does not have knowledge or control over the data being stored. ${ }^{107}$ Therefore, it is unclear whether sharing platforms like YouTube, Dailymotion, or Soundcloud qualify as an active host under the proposal. $^{108}$

There are also several textual issues with this proposal that would need clarification-especially the notion of "large amounts" of works whose scope of application becomes impossible to determine. ${ }^{109}$ However, there is one aspect of the debate surrounding the proposal that has become increasingly sensitive, especially due to recent activism of the CJEU that might be aligning its jurisprudence to the positions held by the Commission in the DSM Draft Directive. Apparently, the proposal implies that hosting providers that do not just merely provide physical facilities, and "thereby" perform an act of communication to the public. ${ }^{110}$ The Commission has reinforced this statement elsewhere. The Communication on Online

\footnotetext{
${ }^{102} I d$. at 20 (emphasis added).

${ }^{103} I d$.

$104 \mathrm{Id}$.

105 Id.

${ }^{106}$ Id.; see also Case C-324/09, L’Oréal SA v. eBay Int'l AG, 2011 E.C.R. I-06011, I-06119, 116.

107 See L'Oréal, 2011 E.C.R. I-06119, qฯ 112-16; see also Van Eecke, supra note 3, at 1472-74 (supporting a "storage but no knowledge" test).

108 See Eleonora Rosati, Why a Reform of Hosting Providers' Safe Harbour is Unnecessary under EU Copyright Law (CREATe Working Paper 2016/11, August 2016).

${ }^{109}$ For a full discussion of these textual issues and an in-depth analysis of the proposal, see Giancarlo Frosio \& Christophe Geiger, Reaction of CEIPI to the European Commission's Proposal on Certain Uses of Protected Content by Online Services (Ctr. for Int'l Intellectual Prop. Studies Position Paper) (forthcoming 2017) (on file with the author).

${ }^{110} I d$.
} 
Platforms and the Digital Single Market noted that rebalancing is needed because "[n]ew forms of online content distribution have emerged that may make copyright-protected content uploaded by end-users widely available. ${ }^{111}$ The Commission characterizes platforms as actively "making available" content uploaded by end-users and considers doing so an act of communication to the public. The reasons for this characterization are quite apparent. If platforms communicate to the public, they would be potentially liable for copyright infringement. Therefore, providers can be obliged to enter into licensing agreements, rather than enter monetization agreements on a voluntary basis.

However, characterizing hosting providers as "communicating to the public" has never been an obvious conclusion under EU law. First, the apparent implication that, unless liability exemptions apply, intermediaries storing and providing public access to protected works would be communicating to the public is novel. Actually, there is no direct relation between liability and exemptions, which function as an extra layer of protection intended to harmonize at the EU level conditions to limit intermediary liability. ${ }^{112}$ The inapplicability of the exemptions does not imply as such that online intermediaries would be liable.

In addition, the proposal, by characterizing active hosts as communicating to the public, would make them directly liable, rather than secondarily liable as commonly understood. According to the European Court of Justice, communicating to the public requires that the user mustin full knowledge of the consequences of its actions - give access to the protected work to an additional public so that, absent that indispensable intervention, that "new" public is unable to enjoy the work. ${ }^{113}$ As end-users physically upload the work - while online intermediaries do not - they first become that necessary indispensable intervention enabling the new public to enjoy the protected work. However, recent CJEU case law has been transitioning to an apparently looser standard, focusing on the essential, rather than the indispensable, role of the user. ${ }^{114}$ This, in turn, would make it easier to construe hosting providers as communicating to the public.

111 See OP\&DSM Communication, supra note 34, at 8 (emphasis added).

112 See Frosio \& Geiger, supra note 109.

113 See Case C-306/05, Sociedad General de Autores v. Rafael Hoteles SA, 2006 E.C.R. I-11519, I11558; Joined Cases C-403 \& 429/08, Football Assoc. Premier League v. QC Leisure, 2011 E.C.R. I9083, I-9239.

114 See Case C-527/15, Stiching Brein v. Jack Frederik Wullems, ECLI:EU:C:2017:300, \ 32 (finding communication to the public in the sale of a multimedia player with pre-installed add-ons, available on the internet, containing hyperlinks to freely accessible website that makes infringing materials available); Case C-610/15, Stichting Brein v. Ziggo BV, XS4ALL Internet BV, ECLI:EU:C:2017:456, ๆ 37. 
Recent CJEU case law qualified this notion of essential intervention by extending it to circumstances not only where, absent that intervention, customers would not be able to access the work, but also where they "would be able to do so only with difficulty." 115 In particular, Ziggo, discussed below, concludes that without the operators of the platform ThePirateBay (TPB) making the platform available and managing it, the users could not share the works or, "at the very least, sharing them on the internet would prove to be more complex." 116

Actually, intermediaries have already been held directly liable for their users' copyright infringement, but only when their involvement in the infringement is so substantial that they have been found to have communicated the works themselves, rather than being used by others to perform the communication. ${ }^{17}$ This line of argument might still distinguish Ziggo - and Wullems - from cases involving UGC platforms targeted by the upcoming reform. In Ziggo, the TPB provided a vast array of functions - such as indexing, categorization, deletion and filtering - that obviously set the platform apart from any mere provision of physical facilities and trespass into a conduct intentionally aimed at facilitating infringement. ${ }^{118}$ In both cases, the CJEU found a specific design to induce copyright infringement, including advertisement or operators' comments on blogs and forums encouraging users to access and download infringing content. ${ }^{119}$ It found that both technologies were primarily designed to infringe copyright, considering, for example, that almost the totality of files shared on the TPB platform infringe copyright. ${ }^{120}$ Absent all these cumulative circumstances — such as might be the case for UGC sharing

\footnotetext{
115 See C-610/15, supra note 114 , at 926.

116 Id. at 936.

117 Standards have varied greatly from jurisdiction to jurisdiction. For example, in the UK, there is clear distinction between primary and secondary infringement, setting a high bar for finding intermediaries directly liable. See, e.g., Twentieth Century Fox Film Corp. v. Newzbin Ltd. [2010] EWHC (Ch) 608, http://www.bailii.org/ew/cases/EWHC/Ch/2010/608.html [https://perma.cc/NQU6-XQBU] (finding an indexing website directly liable for having communicated works to the public because it had "intervened in a highly material way to make the claimants' films available to a new audience, that is to say its premium members," in particular "by providing a sophisticated technical and editorial system which allows its premium members to download all the component messages of the film of their choice upon pressing a button, and so avoid days of (potentially futile) effort in seeking to gather those messages together for themselves"); Football Assoc. Premier League Ltd. v. British Sky Broad. Ltd. [2013] EWHC (Ch) 205, http://www.bailii.org/ew/cases/EWHC/Ch/2013/2058.html [https://perma.cc/HC6F-95EP].

118 See C-610/15, supra note 114, at 93.

119 See C-527/15, supra note 114, at 18 and 50; C-610/15, supra note 114, at 95 . Cf. MGM Studios, Inc. v. Grokster, Ltd., 545 U.S. 913 (2005).

${ }^{120}$ See CJEU, C-610/15, Stichting Brein v. Ziggo BV, XS4ALL Internet BV (Opinion of Advocate General Szpunar), ECLI:EU:C:2017:99, $₫ 23$.
} 
platforms like YouTube, DailyMotion or Soundcloud-traditionally, intermediaries have been held secondarily liable, rather than primarily. In most EU jurisdictions, secondary liability requires highly demanding conditions that are derived from miscellaneous doctrines of tort law, ${ }^{121}$ such as the doctrines of joint tortfeasance, authorization, inducement, common design, contributory liability, vicarious liability, or extra-contractual liability. ${ }^{122}$ In contrast, according to the proposal, intermediary services would automatically be assumed to be infringing and directly liable for infringements materially committed by others. Although recent CJEU case law reinforces the position upheld by the proposal, ${ }^{123}$ it still might be overinclusive and stretch "communication to the public" too far. The broad application of "communication to the public" sought by the Commission's proposal would wind the clock back to the debates in the 1990s, when the introduction of safe harbor provisions for online intermediaries won the day by a narrow margin over initial proposals that held intermediaries fully liable for copyright infringement. ${ }^{124}$

The proposal encourages the use of effective content recognition technologies, such as YouTube's Content ID or other automatic

121 See Kamiel Koelman \& Bernt Hugenholtz, Online Service Provider Liability for Copyright Infringement, (Workshop on Serv. Provider Liab., Geneva, Switz.), Nov. 22, 1999, at 5-8, https://pure.uva.nl/ws/files/3363649/6027_wipo99.pdf [https://perma.cc/E54Q-TKD3]; BÜRGERLICHES GESETZBUCH BGB [Civil Code], §830, translation at https://www.gesetze-im-internet.de/ englisch_bgb/englisch_bgb.html\#p3502 [perma.cc/7KV7-SLWE] (Ger.) (governing joint tortfeasance).

122 There is no case law and no harmonized regulation on secondary copyright liability at the EU level. Each Member State has deployed differing and miscellaneous standards. See Tatiana-Eleni Synodinou, Intermediaries' Liability for Online Copyright Infringement in the EU: Evolutions and Confusions, 31 COMPUTER L. \& SeCURITY ReV. 57, 57 (2015); Christina Angelopoulos, Beyond the Safe Habours: Harmonising Substantive Intermediary Liability for Copyright Infringement in Europe, 3 InTELl. Prop. Q. 253, 254 (2013); Mari Männiko, Intermediary Service Providers' Liability Exemptions: Where Can We Draw the Line?, in Regulating ETECHNOLOGIES IN THE European Union: Normative Realities And TREnds, 119 (Tanel Kerikmäe ed., Springer Int'l Publ'g. 2014) (noting that comparative analysis show that the present legislation is too general and gives too much room for interpretation); Van Eecke, supra note 3, at 1457-61; Broder Kleinschmidt, An International Comparison of ISP's Liabilities for Unlawful Third Party Content, 18 INT'L J.L. \& INFO. TeCH. 332, 345-53 (2010).

123 See Eleonora Rosati, The CJEU Pirate Bay Judgment and its Impact on the Liability of Online Platforms, EUR. INTELL. PROP. REV. (forthcoming, 2017), 1, https://papers.ssrn.com/sol3/ papers.cfm?abstract_id=3006591 [https://perma.cc/AJ46-TNMC] (noting that "[i]n relation to the current EU policy discussion of the so called 'value gap proposal', the judgment reinforces the position of the European Commission, especially the basic idea that the making available, by a hosting provider, of third-party uploaded copyright content may fall within the scope of the right of communication to the public").

124 See Bruce A. Lehman, U.S. Patent \& Trademark Office, Intellectual Property and THE NATIONAL INFORMATION INFRASTRUCTURE: THE REPORT OF THE WORKING GROUP ON INTELLECTUAL PROPERTY RIGHTS 114-24 (1995), https://www.uspto.gov/web/offices/com/doc/ipnii/ ipnii.pdf [perma.cc/V7G4-RDLN]. 
infringement assessment systems, to prevent the availability of infringing content. In practice, the proposal would de facto force intermediaries to develop and deploy monitoring and filtering systems. This proposal follows in the footsteps of a well-established path in recent intermediary liability policy. Recent case law has imposed proactive monitor obligations on intermediaries for copyright infringement-such as Allostreaming in France, Dafra in Brazil, RapidShare in Germany, or Baidu in China. ${ }^{125}$ Actually, the emerging enforcement of proactive monitoring obligations has been spanning the entire spectrum of intermediary liability subject matters: intellectual property, privacy, defamation, and hate/dangerous speech. ${ }^{126}$ In this context, however, notable exceptions - such as the landmark Belen case in Argentina-also highlight a fragmented international response to intermediary liability. ${ }^{127}$ There might be a wellmarked trend in intermediary liability policy leading to the death of "no monitoring obligations." ${ }^{128}$ Current internet policy-especially in Europeis silently drifting away from a fundamental safeguard for users' freedom of expression online that has guarded against any "invisible handshake" between rightholders, online intermediaries, and governments.

125 See APC v. Google, Tribunal de grande instance [TGI] [ordinary court of original jurisdiction] Paris, Nov. 28, 2013 (Fr.), https://www.legalis.net/jurisprudences/tribunal-de-grande-instance-de-parisordonnance-de-refere-28-novembre-2013/ [https://perma.cc/7JA2-37PB]; Nord-Ouest Prod. v. S.A. DailyMotion, Tribunal de grade instance [TGI] [ordinary court of original jurisdiction] Paris, July 13, 2007 (Fr.), https://www.legifrance.gouv.fr/affichJuriJudi.do?oldAction=rechJuriJudi\&idTexte= JURITEXT000018861366\&fastReqId=728956270\&fastPos $=2 \quad$ [https://perma.cc/JX6L-45GZ], rev' $d$, Christian C. v. DailyMotion, Cour de cassation [Cass.] [supreme court for judicial matters] 1 civ., Feb. 17, 2011, No. 09-67.896 (Fr.), https://www.legifrance.gouv.fr/affichJuriJudi.do?oldAction= rechJuriJudi\&idTexte $=$ JURITEXT000023607266 \& fastReqId $=1284420829 \&$ fastPos $=1$

[https://perma.cc/UZN4-YLL8\}; Google Brazil v. Dafra, S.T.J.J., Special Ap. No. 1.306.157-SP, 24.03.2014 (Braz.), https://ww2.stj.jus.br/processo/revista/documento/mediado/?componente= ITA\&sequencial $=1170944 \&$ num_registro $=201102315501 \&$ data $=20140324 \&$ formato $=P D F$

[https://perma.cc/MQ9V-CXJC]; GEMA v. RapidShare, [BGH] [Federal Court of Justice] Nov. 26, 2015, I ZR 03/14 (Ger.), http://juris.bundesgerichtshof.de/cgi-bin/rechtsprechung/document.py? Gericht=bgh\&Art=pm\&pm_nummer=0194/15 [https://perma.cc/C32U-3GNX]; Zhong Qin Wen v. Baidu, 2014 Gao Min Zhong Zi, No. 2045 (Beijing Higher People's Court 2014).

${ }^{126}$ See Google v. Mosley (TGI Paris, November 6, 2013) (France); Mosley v Google [2015] EWHC 59 (QB) (United Kingdom); Rolex v. eBay/Ricardo, supra note 125; Rolex v. eBay (a.k.a. Internetversteigerung II), I ZR 35/04 (BGH, April 19, 2007) (Germany); Rolex v. Ricardo (a.k.a. Internetversteigerung III), Case I ZR 73/05, (BGH, April 30, 2008) (Germany); Delfi AS v. Estonia, No. 64569/09 (ECtHR, June 16, 2015).

${ }^{127}$ See Corte Suprema de Justicia de la Nación [CSJN] [National Supreme Court of Justice], 29/10/2014, “Rodriguez, Maria Belen c. Google, Inc. / daños y perjuicios,” R.522.XLIX, (Arg.).

${ }^{128}$ A detailed discussion of this trend will be the subject of a forthcoming paper. See Giancarlo F. Frosio, The Death of 'No Monitoring Obligations': A Story of Untameable Monsters, 8 J. INTELL ProP. INF. TECH. E-COM. L. (under review) (forthcoming 2017), https://papers.ssrn.com/sol3/ papers.cfm?abstract_id=2980786 [https://perma.cc/8B34-UF2V]. 
At first glance, inconsistency with the EU acquis might irremediably plague the introduction of filtering obligations. The introduction of any filtering technology - thereby imposing a de facto general monitoring obligation as, in order to filter unwanted content, all content must be monitored $^{129}$ - would inevitably call into question necessary coordination with the eCommerce Directive. Apparently, this proposal would contradict the eCommerce Directive's intermediary liability regime - in particular the no-monitoring rule set out in Article 15 of the eCommerce Directive. ${ }^{130}$ The eCommerce Directive prohibits general monitoring obligations, although it does allow national law to provide for monitoring obligations "in a specific case."131 In order to distinguish general from specific monitoring obligations, it should be considered that (1) as an exception, specific monitoring obligations must be interpreted narrowly, (2) both the scope of the possible infringements and the amount of infringements that can be reasonably expected to be identified must be sufficiently narrow, and (3) it must be obvious which materials constitute an infringement. ${ }^{132}$ According to the above, the proposed obligation would fall in the former category, rather than the latter. ${ }^{133}$

It goes without saying, the proposal openly conflicts with consistentand unambiguous-European jurisprudence. The European Court of Justice has reinforced the position that there is no room for general proactive monitoring and filtering mechanisms under EU law. ${ }^{134}$ In multiple cases, the Court has decided that the eCommerce Directive trumps conflicting measures in other intellectual property legislation. ${ }^{135}$ In $S A B A M$ v. Netlog, the Court specifically referenced hosting providers, using language that unmistakably covers the proposal in Article 13. According to the ECJ, European law must be interpreted as preventing nations from requiring a hosting provider to install a system for filtering: (1) information which is stored on its servers by its service users; (2) which applies indiscriminately

\footnotetext{
129 See Case C-360/10, Belgische Vereniging van Auteurs, Componisten en Uitgevers CVBA v. Netlog NV, 2012 EUR-Lex CELEX LEXIS 85 (Feb. 16, 2012), http://eur-lex.europa.eu/legal-content/ EN/TXT/PDF/?uri=CELEX:62010CJ0360\&rid=3 [https://perma.cc/3KRE-UJD8].

130 See eCommerce Directive, supra note 2, at Art. 15, $§ 1$.

131 Id. at Recital 47.

132 Van Eecke, supra note 3, at 1486-87.

${ }^{133} \mathrm{Id}$.

134 See Case C-70/10, Scarlet Extended SA v. Société Belge des Auteurs, Compositeurs et Éditeurs SCRL, 2011 EUR-Lex CELEX LEXIS I-12006, I-120202 (Nov. 24, 2011) http://curia.europa.eu/ juris/document $/$ document.jsf?text $=\&$ docid $=81776 \&$ pageIndex $=0 \&$ doclang $=$ en $\&$ mode $=1$ st $\&$ dir $=\& o c c=f$ irst\&part=1\&cid=131553\#Footref2 [https://perma.cc/FP64-E2L2] (access providers); C-360/10, supra note 129 (hosting providers).

${ }^{135}$ See C-324/09, supra note 106, at $\S 139$; C-70/10, supra note 134, at $\S 40 ; \mathrm{C}-360 / 10$, supra note 129 , at $\S 52$.
} 
to all of those users; (3) as a preventative measure; (4) exclusively at its expense; and (5) for an unlimited period, (6) which is capable of identifying electronic files containing musical, cinematographic, or audiovisual works. ${ }^{136}$

Also, this proposal is systemically inconsistent with EU law because it would create a strict liability regime, rather than a negligence-based regime. ${ }^{137}$ At present, the eCommerce intermediary liability regime can be categorized as a negligence regime based on actual or constructive knowledge. ${ }^{138}$ The hosting exemption works according to a notice and take down regime: upon knowledge of the infringement occurring through its services, the intermediary must act expeditiously to remove the infringing materials. ${ }^{139}$ Introducing a strict liability system for online intermediaries will upset the delicate balance between copyright protection and other fundamental rights like access to information, freedom of expression, and freedom of business. Intermediaries should be governed by the general rules of civil liability (based on negligence), not strict liability IP rules. In the words of the Advocate General of the European Court of Justicewhich, although crafted in the context of trademark infringement online, would apply mutatis mutandis to copyright as well:

Liability rules are more appropriate, since they do not fundamentally change the decentralised nature of the internet by giving trade mark proprietors general - and virtually absolute - control over the use in cyberspace of keywords which correspond to their trade marks. Instead of being able to prevent, through trade mark protection, any possible use-including, as has been observed, many lawful and even desirable uses - trade mark proprietors would have to point to specific instances giving rise to Google's liability in the context of illegal damage to their trade marks. ${ }^{140}$

A negligence-based system would better balance the people's right to information, freedom of expression, and freedom of business with the protection of copyrights.

Filtering technologies - in a related fashion to that just mentioned above - might conflict with fundamental rights by erring on the side of copyright protection. According to the ECJ, filtering would not be as "fair

\footnotetext{
136 See Netlog, supra note 129, at $\S \S 26,52$.

137 Pablo Baistrocchi, Liability of Intermediary Service Providers in the EU Directive on Electronic Commerce, 19 Santa ClaRa High TeCH. L.J. 111, 114 (2002).

${ }^{138}$ Id.

139 See eCommerce Directive, supra note 2, at Art. 14, § 1.

140 Joined Cases C-236, 237 \& 238/08, Google France SARL v. Louis Vuitton Malletier SA, 2009 E.C.R. I-2423, I-2457 (Advocate General Opinion), http://eur-lex.europa.eu/legal-content/EN/ TXT/PDF/?uri=CELEX:62008CC0236\&rid=3 [https://perma.cc/QS3V-USVT].
} 
and proportionate" as the proposal suggests. ${ }^{141}$ Instead, filtering technologies would rather fail to strike a "fair balance" between copyright and other fundamental rights. ${ }^{142}$ They would undermine users' freedom of expression and right to privacy ${ }^{143}$ and the provider's freedom to conduct business. ${ }^{144}$ In particular, in the words of the European Court of Justice, these measures "could potentially undermine freedom of information, since that system might not distinguish adequately between unlawful content and lawful content." ${ }^{145}$ First, automatic infringement assessment systems might undermine the enjoyment of users' exceptions and limitations. ${ }^{146}$ Digital rights management's effects on exceptions and limitations have been highlighted by copious literature. ${ }^{147}$ Similar conclusions apply to this scenario. Automated systems cannot replace human judgment flagging a certain use as fair-or within the scope of an exception or limitation. ${ }^{148}$ Also, complexities regarding the public domain status of certain works, for example, might confuse the content recognition technologies. ${ }^{149}$ At the present level of technological sophistication, false positives (content incorrectly flagged as protected) would have chilling effects that would undermine freedom of information, expression, and possibly business.

Finally, monitoring obligations erect barriers to innovation by making it more expensive for platforms to enter and compete in the market. The proposal's suggested monitoring obligations would force intermediaries to develop and deploy costly technology. ${ }^{150}$ The ECJ has emphasized in the past that such an obligation "would result in a serious infringement of the freedom of the hosting service provider to conduct its business." ${ }^{51}$ In particular, according to the ECJ, this obligation would be contrary to

\footnotetext{
141 See Netlog, supra note 129 , at $\S 34$.

142 See Charter of Fundamental Rights of the European Union, 2012 O.J. (C326) 391.

143 Id., at Arts. 8, 11.

144 Id., at Art. 16.

145 Netlog, supra note 129 , at $\S 50$.

146 Id.; see also Leron Solomon, Fair Users or Content Abusers? The Automatic Flagging of NonInfringing Videos by Content ID on Youtube, 44 HofSTRA L. REV. 237, 255 (2015); Corinne Hui Yun Tan, Lawrence Lessig v Liberation Music Pty Ltd: YouTube's Hand (or Bots) in the Over-Zealous Enforcement of Copyright, 36 EUR. INTELL. PROP. R. 347, 350 (2014).

147 See Frosio, supra note 97, at 99-103, 135-41 (discussing most of the relevant literature and major threats that technological protection measures pose for fair dealings, as well as privileged and fair

148 See Dan L. Burk \& Julie E. Cohen, Fair Use Infrastructure for Rights Management Systems, 15 HARV. J.L. \& TECH. 41, 59 (2001); Matthew Sag, Internet Safe Harbors and the Transformation of Copyright Law, 93 NOTRE DAME L. REV. (forthcoming 2017) (manuscript at 55) (on file with author).

149 See Netlog, supra note 129 , at $\S 50$.

150 See Frosio, supra note 97 , at 88.

151 Netlog, supra note 129 , at $\S 46$.
} uses). 
Article 3 of the Enforcement Directive, which provides that "procedures and remedies necessary to ensure the enforcement of the intellectual property rights ... shall not be unnecessarily complicated or costly ... and shall be applied in such a manner as to avoid the creation of barriers to legitimate trade." ${ }^{152}$ Whether technology is too costly-therefore limiting market incentives for present market players - might be up to debate as shown by the Allostreaming case in France and the Dafra case in Brazil. ${ }^{153}$ In both cases Google's so-called "technical defense"-asserting that filtering was too costly and therefore technically unfeasible-was refuted by the courts on the basis of expert-testimony reports to the contrary. ${ }^{154}$ In any event, the proposal's suggested monitoring obligation would have the most negative effect on companies that do not currently own any proprietary recognition technology, widening the gap between established and upcoming intermediaries. In particular, European intermediaries will be at a disadvantage because they will have to license filtering technologies from US companies like Google/YouTube and Audible Magic ${ }^{155}$ because currently no European companies make competitive filtering technologies. As most established market players are US-based, this proposal might once again be a bad tradeoff for European companies - and push the Digital Single Market further away, rather than promoting it.

\section{Notice and Take-Down, Notice and Action, Notice and Stay-Down}

The proposal would also require intermediaries to "put in place complaints and redress mechanisms that are available to users in case of disputes" over filtered content. ${ }^{156}$ The proposal does not develop further on how this counter-notice mechanism should work in practice. It does not provide for the development of best practices or standardization for counter-notices, while it does so for filtering mechanisms. ${ }^{157}$ More importantly, little or nothing is known on how filtering measures will work in practice. Should intermediaries filter everything under the sun? Should they apply recognition technologies only to a preexisting blacklist of protected works? Most likely, the specifics of both the filtering and redress system might result from voluntary efforts and best practices promoted by

152 See Enforcement Directive, supra note 21, at Art. 3.

153 See APC, supra note 125; Dafra, supra note 125.

154 Id.

155 See About, AUDIBLE MAGIC, http://www.audiblemagic.com (a company labeling itself as "the leader in automated identification of audio and visual content for web media platforms and social networks").

156 DSM Directive Proposal, supra note 47, at Art. 13, 2.

157 Id., at Art. 13, § 3; see also Husovec, supra note 48, at 3. 
the industry alone, resembling closely a sectorial notice-and-take-down system.

In this regard, it is odd that the proposal requires intermediaries to provide a redress mechanism for proactive takedowns, while overlooking the issue of a legislatively mandated - and long-awaited-horizontal notice-and-take-down system under the eCommerce Directive framework. ${ }^{158}$ For the sake of systemic consistency, EU law should first set up a general notice-and-take-down and counter-notice system. ${ }^{159}$ However, this is apparently not likely: as mentioned in the OP\&DSM Communication, EU-wide notice-and-action procedures will be postponed for now as the Commission will assess the impact of ongoing reforms first. ${ }^{160}$

For the future, a couple of additional options-besides the aforementioned horizontal notice-and-takedown system-are being considered. First, a sectorial, problem-driven approach might utilize noticeand-action procedures with different requirements for the content of the notice. ${ }^{161}$ According to the results of the Consultation on Online Intermediaries, different categories of illegal content require different notice-and-action procedures, especially content related to intellectual property rights, child abuse content, racism, and xenophobia. ${ }^{162}$ Second, the Enforcement Directive might also be amended to explicitly establish that national courts must be allowed to order intermediaries to take measures aimed not only at ending past and ongoing infringements, but also at preventing further infringements. In that respect, according to the Consultation on Modernization of IPRs' Enforcement, the Directive should establish criteria on how "take down and stay down" should be undertaken

\footnotetext{
158 See eCommerce Directive, supra note 2, at Art. 21, $\$ 2$ (foreseeing the possibility of the introduction of a complete notice-and-take-down procedure).

159 See Open Letter from European Research Centres, EU Copyright Reform Proposals Unfit for the Digital Age, 6 (Feb. 24, 2017), http://www.create.ac.uk/policy-responses/eu-copyright-reform/ [https://perma.cc/P97E-PYYH]; Christina Angelopoulos, On Online Platforms and the Commission's New Proposal for a Directive on Copyright in the Digital Single Market, at 44 (Ctr. for Intellectual Prop. \& Info. Law, Univ. of Cambridge), Jan. 2017, https://juliareda.eu/wpcontent/uploads/2017/03/angelopoulos_platforms_copyright_study.pdf [https://perma.cc/3MA3-8BXE] (both suggesting the introduction of a horizontal notice-and-action framework for hosting providers instead of the current Article 13)

${ }^{160}$ See OP\&DSM Communication, supra note 34, at 9.

161 See Commission, supra note 34, at 16-17; see also Aleksandra Kuczerawy, Intermediary Liability \& Freedom of Expression: Recent Developments in the EU Notice \& Action Initiative, 31 COMPUTER L. \& SECURITY REV. 46, 52 (2015).

162 See Commission, supra note 34 , at 16-17.
} 
without establishing a general monitoring obligation. ${ }^{163}$ The viability of this approach remains to be seen.

\section{CONCLUSION}

The upcoming European Digital Single Market reform endorses a reaction to the platform economy that might prove a bad policy approach. A narrative emphasizing the "value gap"-rather than the added value - of the platform economy is counter-intuitive and disconnected from empirical evidence. The Commission's reform package is apparently based solely on content industry assumptions and ignores much evidence that shows the positive effects that platforms, the internet, and digitization have had on creativity. Overlooking this empirical evidence might result in a reform that will prove obsolete before it is implemented, and possibly be detrimental for the Digital Single Market.

In addition, the present reform proposal might threaten systemic consistency. The reform suggests revising intermediary liability principles through a so-called "sectorial approach," rather than amending the eCommerce Directive. This policy strategy is a sloppy attempt to circumvent the lack of consensus behind an amendment to the present intermediary liability regimes that might create unavoidable conflicts between norms. Intermediary liability reform should happen first and foremost in the context of the eCommerce Directive, rather than through sectorial copyright and audio-visual reform or the promotion of voluntary self-regulatory actions.

Finally, the proposed EU reform deploys a strategy that would apparently turn online intermediaries into internet police. In truth, this comes as little surprise. Since the inception of the internet, governments and IP rightholders have attempted to enlist intermediaries to rid the internet of allegedly infringing and illicit materials. Proactive monitoring and "notice and stay-down" regimes would definitely be a step in that direction. Meanwhile, the endorsement of voluntary measures as a privileged tool to curb illicit and infringing activities online makes intermediaries prone to serve governmental purposes under murky, privately-enforced standards, rather than transparent legal obligations duly enforced by delegated agencies or the judiciary. In this sense, the intermediary liability discourse is shifting towards an intermediary responsibility discourse. This process might be pushing an amorphous notion of responsibility that incentivizes intermediaries' self-intervention to police allegedly infringing activities on the internet. Under this approach,

163 See Commission, supra note 20, at 50. 
due process and fundamental guarantees are replaced by algorithmic enforcement, silencing speech according to the mainstream ethical discourse. Ironically, such reforms might end up achieving the opposite of a culturally independent European Digital Single Market by promoting globalized enforcement via algorithms developed and controlled by major Silicon Valley companies. 